Artikel Riset

DOI : 10.33751/jf.v9i2.1611
Fitofarmaka Jurnal Ilmiah Farmasi

Vol.9, No.2, Desember 2019 : 123-130

p-ISSN : 2087-9164 e-ISSN : 2622-755X

\title{
UJI AKTIVITAS ANTIBAKTERI EKSTRAK BUAH DAN DAUN MENGKUDU (Morinda citrifolia L.) TERHADAP BAKTERI PENYEBAB JERAWAT (Staphylococcus epidermidis)
}

\author{
Prasetyorini $^{{ }^{*}}$, Novi Fajar Utami ${ }^{2}$, Alfi Syahri Sukarya ${ }^{3}$ \\ ${ }^{1}$ Program Studi Biologi, FMIPA Universitas Pakuan, PO Box 452 Bogor 16143 \\ ${ }^{2,3}$ Program Studi Farmasi FMIPA Universitas Pakuan, PO Box 452 Bogor 16143 \\ West Java, Indonesia \\ *E-mail: prasetyorini67@yahoo.co.id
}

Diterima : 15 November 2019 Direvisi : 30 November 2019 Disetujui : 1 Desember 2019

\begin{abstract}
ABSTRAK
Jerawat merupakan penyakit pada permukaan kulit. Terjadi akibat tersumbatnya folikel polisebase, disebabkan oleh infeksi bakteri (Staphylococcus epidermidis). Tanaman yang memiliki potensi sebagai agen antibakteri adalah tanaman mengkudu, yang terbukti memiliki kandungan senyawa antrakuinon, alkaloid dan flavonoid. Penelitian ini bertujuan untuk menentukan karakteristik ekstrak buah dan daun mengkudu serta aktivitas antibakteri terhadap bakteri Staphylococcus epidermidis. Dengan menggunakan metode ekstraksi maserasi etanol 96\%. Pengujian Lebar Daerah Hambat (LDH) dengan metode difusi kertas cakram dan Konsentrasi Hambat Minimum (KHM) dengan metode dilusi agar. KHM pada konsentrasi 25\%, 30\%, 35\% dan $40 \%$. LDH dilakukan pada konsentrasi 40\%, 50\% dan 60\%. Hasil ekstrak etanol 96\% buah dan daun mengkudu memiliki KHM pada konsentrasi $40 \%$ dan LDH buah 3,1 mm pada konsentrasi $50 \%$ dan $60 \%$. Ekstrak daun mengkudu memiliki LDH 2,5 mm pada konsentrasi $60 \%$.
\end{abstract}

Kata kunci: Mengkudu, buah, daun, staphylococcus epidermidis

\section{ANTIBACTERIAL ACTIVITY OF FRUIT AND NONI LEAF (Morinda citrifolia L.) AGAINST ACNE BACTERIA (Staphylococcus epidermidis)}

\begin{abstract}
Acne is a disease on the surface of the skin. Occurs due to blocked polysebase follicles, caused by a bacterial infection (Staphylococcus epidermidis). Plants that have the potential as an antibacterial agent are noni plants, which are proven to contain anthraquinone compounds, alkaloids and flavonoids. This study aims to determine the characteristics of noni fruit and leaf extracts and the antibacterial activity against Staphylococcus epidermidis bacteria. By using 96\% ethanol maceration extraction method. Inhibit Region Width test with paper diffusion method and Minimum Inhibitory Concentration (MIC) with agar dilution method. MIC at concentrations of $25 \%, 30 \%, 35 \%$ and $40 \%$. Inhibit Region Width is carried out at concentrations of $40 \%$, $50 \%$ and $60 \%$. The results of $96 \%$ ethanol extract of noni fruit and leaves have MIC at a concentration of $40 \%$ and Inhibit Region Width fruit of $3.1 \mathrm{~mm}$ at a concentration of
\end{abstract}


$50 \%$ and $60 \%$. Noni leaf extract has an Inhibit Region Width of $2.5 \mathrm{~mm}$ at a concentration of $60 \%$.

Key words: Morinda citrifolia L., fruit, leaf, staphylococcus epidermidis

\section{PENDAHULUAN}

Jerawat atau acne merupakan penyakit pada permukaan kulit wajah, leher, dada, dan punggung yang muncul pada saat kelenjar minyak pada kulit terlalu aktif sehingga pori-pori kulit akan tersumbat oleh timbunan lemak yang berlebihan (Djajadisastra, 2009). Jerawat umumnya dapat mempengaruhi individu sejak kecil hingga dewasa, dan paling sering terjadi pada masa remaja (Jonette K \& Shiman M, 2009). Jerawat tidak mengancam jiwa tetapi jerawat parah dapat mempengaruhi psikologis dan kegiatan sosial (Monaj A et al, 2014).

Mikroorganisme penyebab jerawat ikut berperan dalam pathogenesis penyakit ini. Ada faktor-faktor penyebab lainnya termasuk faktor genetik, usia, ras, kulit putih, kosmetik, hormon, makanan, banyak pekerjaan dan stress (Mitsui, 1997). Bakteri yang umum dapat menginfeksi jerawat yaitu, Staphylococcus epidermidis. Pengo-batan jerawat biasanya menggunakan antibiotik yang dapat menghambat inflamasi dan membunuh bakteri. Namun, penggunaan antibiotik jangka panjang selain menimbulkan resistensi juga dapat menimbulkan kerusakan organ dan imunohipersensitivitas (Djajadisastra dan Joshita, 2009). Salah satu tanaman yang memiliki potensi dalam pengobatan terutama sebagai agen antibakteri adalah tanaman mengkudu yang terbukti memiliki kandungan senyawa antrakuinon, alkaloid flavonoid dan sebagainya yang berkhasiat sebagai antibakteri. Alkaloid, flavonoid, dan antrakuinon yang terbukti mempunyai efek farmakologik sebagai lisosim terhadap sel bakteri. Saponin, dan tanin merupakan campuran dalam antra-kuinon yang bersinergi dan berkontribusi menjadi suatu khasiat penyembuhan yang bersifat analgesik, antiseptik, antiinflamasi, antibakteri dan antijamur (Olivia, 2017). Mengkudu memiliki jangkauan luas efek terapi seperti antivirus, antitumor, anthelmitik, hipotensi, dan meningkatkan sistem imun (Sridevi N et al, 2013). Tanaman mengkudu terutama buahnya memiliki sifat gizi dan fungsional, efek menguntungkan ini terjadi karena adanya beberapa kandungan senyawa aktif ( $\mathrm{Z}$ Mohd et al, 2007). Tanaman mengkudu menunjukkan profil terapeutik dan keamanan yang sangat tinggi dan dapat digunakan sebagai penambah kesehatan (M Ali et al, 2016).

Bakteri yang digunakan Staphylococcus epidermidis, merupakan bakteri gram positif, bersifat sebagai anaerob fakultatif, tumbuh lebih cepat dan lebih banyak dalam keadaan aerobik. Suhu optimum $35-40^{\circ} \mathrm{C}$ (Pelczar et al, 2008) dan pengujian antibakteri menggunakan metode difusi dan dilusi dengan metode secara Kirby-Bauer.

\section{METODE PENELITIAN Alat dan Bahan}

Alat yang digunakan pada penelitian ini adalah autoklaf, beker glas (pyrex), bunsen, botol coklat, cawan petri (Pyrex), corong, Erlenmeyer (Pyrex), gelas ukur, kapas, kain batis, kertas cakram, kurs, Laminar Air Flow (LAF), mikropipet (Proline plus $\left.{ }^{\circledR}\right)$, neraca digital, oven, ose, pipet tetes, penangas air, rotary evaporator, tabung reaksi 
(Pyrex), tanur, timbangan analitik, spirtus, serta alat-alat gelas lainnya.

Bahan yang digunakan pada penelitian ini adalah aquadest, amoksisilin, bakteri Staphylococcus epidermidis, buah masak dan daun (P5P9) mengkudu, etanol $96 \%, \mathrm{FeCl}_{3}, \mathrm{HCl}$, $\mathrm{NaCl}$, Nutrient Agar (NA), pereaksi bouchardat, pereaksi dragendrof, pereaksi mayer, pereaksi wagner.

\section{Prosedur Kerja}

\section{Pembuatan Serbuk Simplisia}

Buah dan daun mengkudu segar yang telah diperoleh disortasi basah, dicuci bersih, dikeringkan dengan menggunakan oven sampai kering, kemudian disortasi kering, dihaluskan hingga diperoleh simplisia serbuk dan diayak dengan menggunakan mesh 40 (DepKes RI, 2000).

\section{Pembuatan Ekstrak}

Pembuatan ekstrak buah dan daun mengkudu dilakukan dengan menggunakan metode maserasi. Maserasi dilakukan dengan menggunakan pelarut etanol 96\% (1:10). Sebanyak 100 gram simplisia dimasukkan kedalam botol ditambahkan etanol 96\% sebanyak 1000 $\mathrm{mL}$ dan direndam dengan dikocok tiap 6 jam selama 24 jam, kemudian disaring untuk memisahkan ampas dan filtrat, lalu ampas tersebut dimaserasi dengan menggunakan pelarut etanol $96 \%$, proses maserasi dilakukan selama 3 hari. Filtrat yang dihasilkan kemudian dikumpulkan untuk dipekatkan dengan rotary evaporator hingga didapat ekstrak kental (DepKes RI, 2000).

\section{Uji Karakteristik Ekstrak Buah dan Daun Mengkudu \\ Penetapan Kadar Air}

Penetapan kadar air dilakukan dengan menggunakan metode gravi- metri. Sebanyak \pm 2 g simplisia serbuk buah dan daun mengkudu dimasukkan ke dalam wadah yang telah di tera dengan dikeringkan pada suhu $105^{\circ} \mathrm{C}$ selama 1 jam. Pengeringan dan penimbangan ulang dilakukan pada jarak 1 jam hingga perbedaan antara penimbangan berturutturut tidak melebihi dari $0,25 \%$. Syarat kadar air simplisia serbuk pada umumnya yaitu tidak lebih dari $10 \%$ (Depkes RI, 1995).

\section{Penetapan Kadar Abu}

Simplisia serbuk buah dan daun mengkudu ditimbang seksama $\pm 2 \mathrm{~g}$ kemudian dimasukkan kedalam krus silikat yang telah di pijar dan di tara. Pemijaran dilakukan pada suhu $\pm 600^{\circ} \mathrm{C}$ kemudian didinginkan dan ditimbang sampai bobot konstan dengan selisih < $0,25 \%$. Kadar abu simplisia tidak boleh lebih dari 10\% (Kemenkes RI, 2013).

\section{Uji Fitokimia}

Uji fitokimia yang dilakukan terdiri dari uji alkaloid dengan menggunakan pereaksi mayer, bounchardat dan dragendrof. Uji flavonoid dengan menggunakan serbuk Mg. Uji saponin dengan melihat busa yang terbentuk hingga stabil setelah pengocokan. Uji tanin menggunakan $\mathrm{FeCl}_{3}$.

\section{Penyiapan Inokulum \\ Sterilisasi Alat dan Bahan}

Alat-alat yang digunakan dalam pengujian, disterilkan terlebih dahulu dengan cara dibungkus kertas polos, lalu dimasukkan ke dalam autoklaf pada suhu $121^{\circ} \mathrm{C}$ selama 15 menit, kemudian alatalat dikeringkan dengan cara dimasukkan ke dalam oven pada suhu $100^{\circ} \mathrm{C}$ selama 30 menit. 


\section{Pembuatan Media Bakteri}

Media yang digunakan adalah media Nutrient Agar (NA). Media NA dibuat dengan cara melarutkan $28 \mathrm{~g}$ serbuk NA dalam $1000 \mathrm{~mL}$ akuades, dipanaskan dan diaduk hingga homogen. Kemudian disterilkan dengan autoklaf pada suhu $121^{\circ} \mathrm{C}$ selama 15 menit dengan tekanan $1 \mathrm{~atm}$. Masukkan kedalam cawan petri yang telah steril dan dibiarkan sampai memadat.

\section{Regenerasi Bakteri Uji}

Bakteri yang akan digunakan sebelum dipakai harus diregenerasi terlebih dahulu. Bakteri yang berasal dari kultur primer, mula-mula dibiakkan ke dalam agar miring NA, lalu diambil satu ose dan digoreskan ke dalam agar miring NA kemudian diinkubasi selama 24 jam dengan suhu $37^{\circ} \mathrm{C}$ (biakan yang sudah tumbuh disimpan di lemari pendingin pada suhu $4^{\circ} \mathrm{C}$ sebagai stok).

\section{Penetapan Konsentrasi Hambat Minimum (KHM) dan Lebar Daerah Hambat (LDH)}

Penetapan KHM dilakukan dengan menggunakan metode dilusi agar. Sebanyak 0,2 mL bakteri Staphylococcus epidermidis dimasuk-kan ke dalam 20 mL NA, kemudian ditambahkan $1 \mathrm{~mL}$ ekstrak pada konsentrasi uji, lalu diinkubasi selama 24 jam pada suhu $37^{\circ} \mathrm{C}$ di inkubator. Setelah diinkubasi diamati pertumbuhan bakterinya. Konsentrasi terendah ekstrak yang tidak ditumbuhi bakteri merupakan konsentrasi hambat minimum (KHM).

Penetapan LDH menggunakan metode difusi cakram. Yaitu dengan dilihat daerah atau zona bening yang terbentuk di sekitar kertas cakram. Sebanyak 0,2 $\mathrm{mL}$ bakteri dengan konsentrasi $10^{-6}$ hasil pengenceran dituangkan kedalam cawan petri yang berisi NA dengan suhu $40^{\circ} \mathrm{C}$, kemudian digerakkan melingkar untuk menyebarkan bakteri secara merata. Setelah Agar memadat diletakkan kertas cakram yang mengandung ekstrak di atasnya. Cawan petri di inkubasi selama 24 jam pada suhu $37^{\circ}$ C. Aktivitas antibakteri diketahui dengan timbulnya zona hambat yaitu daerah bening di sekitar kertas cakram yang menunjukkan pertumbuhan bakteri. Diamati dan diukur lebar daerah hambat yang terbentuk.

\section{HASIL DAN PEMBAHASAN}

\section{Hasil Uji Karakteristik Buah dan Daun} Mengkudu

\section{Penetapan Kadar Air Simplisia dan} Ekstrak

Penetapan kadar air bertujuan untuk memberikan batasan minimal atau tentang besarnya kandungan air dalam suatu bahan (Depkes RI, 2000). Kadar air serbuk dan ekstrak dilakukan pengujian sebanyak dua kali (duplo). Kadar air serbuk simplisia adalah memenuhi syarat umum kadar air simplisia yakni $<10 \%$ (Depkes RI, 1995).

Tabel 1. Data Kadar Air Simplisia dan

\begin{tabular}{ccc} 
& Ekstrak & \\
\hline Sampel & $\begin{array}{c}\text { Kadar Air } \\
(\%)\end{array}$ & Syarat (\%) \\
\hline $\begin{array}{c}\text { Serbuk } \\
\text { simplisia } \\
\text { buah }\end{array}$ & 6,584 & $<10$ \\
$\begin{array}{c}\text { Serbuk } \\
\text { simplisia } \\
\text { daun }\end{array}$ & 4,415 & $<10$ \\
Ekstrak & & \\
etanol 96\% \\
buah
\end{tabular}


Penetapan Kadar Abu Simplisia dan Ekstrak

Penetapan kadar abu total dilakukan dengan proses pemanasaan sampel uji menggunakan tanur dengan suhu $500-600^{\circ} \mathrm{C}$, dimana pada suhu tersebut senyawa organik dan turunannya terdestruksi dan menguap sehingga tinggal unsur mineral dan organiknya. (Depkes RI, 2000). Data hasil pada uji kadar abu total dapat dilihat pada Tabel 2.

Tabel 2. Hasil Penetapan Kadar Abu Serbuk dan Ekstrak.

\begin{tabular}{cccc}
\hline \multirow{2}{*}{ Jenis } & \multicolumn{2}{c}{ Tanaman } & \\
\cline { 2 - 3 } Sampel & $\begin{array}{c}\text { Daun } \\
\text { Mengkudu. }\end{array}$ & $\begin{array}{c}\text { Buah } \\
\text { Mengkudu. }\end{array}$ & $\begin{array}{c}\text { Syarat } \\
(\%)\end{array}$ \\
\hline Serbuk & $3,42 \%$ & $3,49 \%$ & $<7$ \\
Ekstrak & $4,553 \%$ & $6,676 \%$ & $<12$ \\
\hline
\end{tabular}

Berdasarkan hasil uji kadar abu menunjukan bahwa pada simplisia serbuk buah mengkudu adalah 3,49 \%, dan pada simplisia serbuk daun mengkudu adalah $3,42 \%$. Hasil tersebut sesuai syarat umum yaitu $<7 \%$. Sedangkan pada kadar abu total ekstrak etanol $96 \%$ buah mengkudu adalah

6,676 \%, dan kadar abu total ekstrak etanol $96 \%$ daun mengkudu adalah 4,553 $\%$. Dari hasil data kadar abu total yang di dapat bahwa simplisia dan ekstrak etanol $96 \%$ pada pengujian karakteristik kadar abu total ini memenuhi persyaratan syarat 3-5\% (Voight,1994).

\section{Hasil Uji Fitokimia}

Uji fitokimia dilakukan untuk mengetahui senyawa yang terkandung dalam suatu tanaman. Hasil uji fitokimia pada famili Rubiaceae dengan menggunakan dua bagian tumbuhan yaitu ekstrak etanol $96 \%$ buah dan daun mengkudu, terjadi proses reaksi perubahan warna dan endapan yang terbentuk sehingga menyatakan bahwa positif mengandung senyawa alkaloid, flavonoid, saponin dan tannin (Tabel 3).

Tabel 3. Hasil Skrining Fitokimia

\begin{tabular}{|c|c|c|c|c|}
\hline \multirow[b]{2}{*}{ Simplisia } & \multicolumn{4}{|c|}{ Senyawa Kimia } \\
\hline & $\begin{array}{c}\text { Alkaloi } \\
\mathrm{d}\end{array}$ & Flavonoid & Saponin & Tanin \\
\hline Rubiaceae & & & & \\
\hline Buah Mengkudu & + & + & + & + \\
\hline Daun Mengkudu & + & + & + & + \\
\hline
\end{tabular}

\section{Hasil Penetapan Konsentrasi Hambat Minimum (KHM) dan Lebar Daya Hambat (LDH) \\ Hasil Uji Konsentrasi Hambat Minimum}

Pengujian KHM dilakukan dengan metode difusi yang digunakan untuk mendapatkan konsentrasi minimum pada ekstrak etanol $96 \%$ buah dan daun mengkudu terhadap pertumbuhan bakteri Staphylococcus epidermidis. Adanya daya hambat dalam senyawa antibakteri tersebut ditandai dengan tidak adanya pertumbuhan bakteri pada media (Jawetz et al, 1996). Hasil uji KHM yang diperoleh pada ekstrak etanol $96 \%$ dari buah mengkudu terhadap bakteri Staphylococcus epidermidis. Pada konsentrasi $25 \%$ dan $30 \%$ belum mampu menghambat pertumbuhan bakteri. Dan pada konsentrasi $35 \%$ menunjukkan adanya sedikit pertumbuhan bakteri. Konsentrasi hambat minimum buah mengkudu terhadap bakteri 
Staphylococcus epidermidis terdapat pada konsentrasi $40 \%$. Berdasarkan hasil uji konsentrasi hambat minimum yang diperoleh pada ekstrak etanol $96 \%$ dari daun mengkudu. Terhadap bakteri Staphylococcus epidermidis. Terdapat sedikit pertumbuhan bakteri pada konsentrasi 35\%, dan konsentrasi $40 \%$ menunjukkan adaya hambatan karena tidak terjadi pertumbuhan bakteri pada konsentrasi tesebut. Sehingga hambatan minimum berada pada konsentrasi $40 \%$. Konsentrasi tersebut cukup baik, karena pada konsentrasi yang lebih rendah masih terdapat pertumbuhan bakteri yang belum dapat menghambat secara optimal.

\section{Hasil Uji Lebar Daerah Hambat}

Uji Lebar Daerah Hambat (LDH) oleh ekstrak etanol $96 \%$ buah dan daun mengkudu dilakukan terhadap bakteri Staphylococcus epidermidis dengan metode difusi agar menggunakan kertas cakram dengan diameter $6 \mathrm{~mm}$. Konsentrasi yang digunakan yaitu $40 \%$, $50 \%$, dan $60 \%$. Sedangkan kontrol positif dan kontrol negatif yang digunakan pada bakteri Staphylococcus epidermidis yaitu Amoxicillin dan kontrol negatif yang digunakan adalah aquadest. Hasil pengamatan dan pengukuran LDH menunjukkan setiap ekstrak pada bakteri yang sama memiliki tingkatan efektivitas antibakteri yang berbeda. Pengukuran lebar daya hambat dilakukan terhadap area bening di sekitar cakram seperti yang dilihat pada Gambar 1.

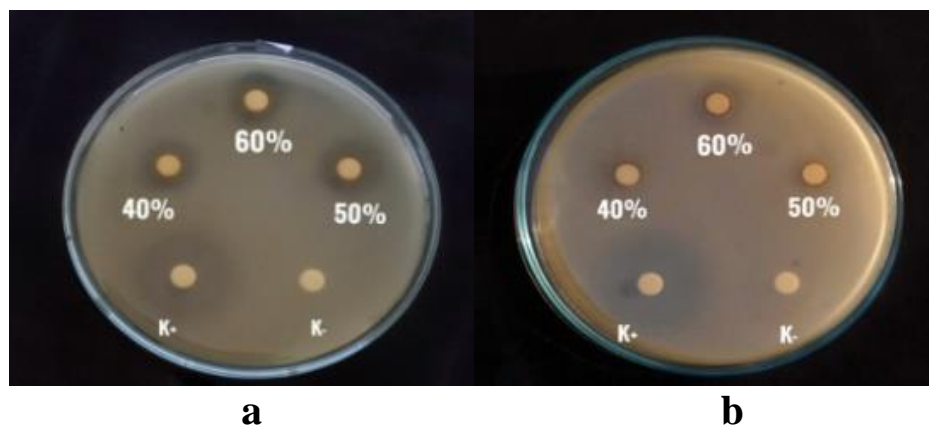

Gambar 1. Lebar daerah hambat ekstrak etanol $96 \%$ buah mengkudu terhadap bakteri Staphylococcus epidermidis (a), Luas daerah hambat ekstrak etanol $96 \%$ daun mengkudu terhadap bakteri Staphylococcus epidermidis (b).

Gambar diatas menunjukkan bahwa ekstrak etanol $96 \%$ buah dan daun mengkudu memiliki aktivitas antimikroba terhadap Staphylococcus epidermidis. Dengan pelarut etanol $96 \%$ memiliki lebar daerah hambat yang rendah dibandingkan dengan kontrol positif. Hasil tersebut dapat dilihat pada Tabel 4.
Berdasarkan Tabel 4 dapat dilihat bahwa tanaman famili Rubiacea yaitu buah dan daun mengkudu tersebut memiliki aktivitas antibakteri namun aktivitas antibakteri tersebut masih tergolong dalam kategori lemah. 
Tabel 4. Hasil Lebar Daerah Hambat (LDH)

\begin{tabular}{cccc}
\hline Sampel & Konsentrasi & LDH $(\mathrm{mm})$ & Keterangan \\
\hline \multirow{3}{*}{ Buah Mengkudu } & $40 \%$ & 2,6 & Lemah \\
& $50 \%$ & 3,1 & Lemah \\
Kontrol + (Amoxicilin) & $60 \%$ & 3,5 & Lemah \\
& $10 \mathrm{ppm}$ & 8 & Kuat \\
Daun Mengkudu & $40 \%$ & 1,6 & Lemah \\
& $50 \%$ & 2,1 & Lemah \\
Kontrol + (Amoxicilin) & $60 \%$ & 2,5 & Lemah \\
\hline
\end{tabular}

Ekstrak etanol $96 \%$ buah dan daun mengkudu tersebut dapat digunakan sebagai antibakteri karena senyawa kimia yang terkandung pada ekstrak seperti alkaloid, flavonoid, saponin dan tanin. Mekanisme kerja alkaloid sebagai antibakteri yaitu, dengan mengganggu komponen penyusun peptidoglikan pada sel bakteri, sehingga lapisan dinding sel tidak terbentuk secara utuh dan menyebabkan kematian sel tersebut (Darsana dkk, 2012). Senyawa flavonoid berpotensi sebagai senyawa antibiotik dan antibakteri. Senyawa flavonoid disintesis oleh tanaman sebagai sistem pertahanan dan dalam responnya terhadap infeksi oleh mikroorganisme (Apriani, 2013). Senyawa saponin memiliki aktivitas antimikroba karena mempunyai sifat sebagai surfaktan dengan gugus polar (gula) dan nonpolar (terpenoid) sehingga dapat menurunkan tegangan permukaan dinding sel mikroba dan dapat memecah lapisan lemaknya, yang akan mengganggu permeabilitas dinding sel mikroba. Hal tersebut mengakibatkan proses difusi bahan atau zat-zat yang diperlukan oleh mikroba dapat terganggu, yang kemudian terjadi pembengkakan sel yang pecah. Senyawa tanin sebagai antibakteri adalah memalui reaksi dengan membran sel, inaktivasi enzim dan inaktivasi fungsi materi genetik (Harborne, 1987).

\section{KESIMPULAN}

1. Ekstrak etanol $96 \%$ buah dan daun mengkudu memiliki aktivitas antibakteri terhadap Staphylococcus epidermidis dengan nilai KHM masing-masing pada konsentrasi $40 \%$. Dan pada ekstrak buah mengkudu dengan konsentrasi $50 \%$ dan $60 \%$ didapat nilai LDH masing-masing 3,1 $\mathrm{mm}$ dan pada daun memiliki nilai LDH $2.5 \mathrm{~mm}$ pada konsentrasi $60 \%$.

2. Ekstrak etanol $96 \%$ buah dan daun mengkudu memenuhi persyaratan karakteristik Materia Medika Indonesia (kadar abu ekstrak dibawah 12\%). Serta memiliki kandungan alkaloid, flavonoid, saponin dan tanin

\section{REFERENSI}

Apriani, S.P. 2013. Senyawa Flavonoid Yang Bersifat Antibakteri Dari Akway (Drimys becariana. Gibbs). Chemistry Progress. 6(1): 34-37.

Darsana, I., Besung, I \& Mahatmi H. 2012. Potensi Daun Binahong (Anredera cordifolia (Tenre) Steenis) Dalam Menghambat Pertumbuhan Bakteri Eschericia coli Secara In Vitro. Indonesia Venerius 1(3).

Departemen Kesehatan RI. 1995. Materia Medika Indonesia Edisi VI. Jakarta : Direktorat Jendral Pengawasan Obat dan Makanan. 
2000. Parameter Standarisasi Umum Ekstrak Tumbuhan Obat. Jakarta : Direktorat Jendral Pengawasan Obat dan Makanan.

Djajadisastra, Joshita. 2009. Formulasi gel topical dari ekstrak Nerii folium dalam sediaan anti jerawat. Jurnal farmasi indonesia. Fakultas MIPA Jakarta : Universitas Indonesia.

Harborne, J.B. 1987. Metode Fitokimia

$\begin{array}{lrr}\text { :Penuntun } & \text { Cara } & \begin{array}{r}\text { Modern } \\ \text { Menganalisis }\end{array} \\ \text { (Penerjemah: } & & \begin{array}{r}\text { Kosasih } \\ \text { Padmawinata, Iwang }\end{array} \\ \text { Soediro). }\end{array}$

Jawetz, Melnick dan Adelberg. 1996. Mikrobiologi Kedokteran. edisi 20. EGC.Jakarta.

Keri, J., \& Shiman, M. 2009. An update on the management of acne vulgaris. Clinical, cosmetic and investigational dermatology. 2 , 105-110.

Kemenkes RI. 2013. Peraturan Menteri Kesehatan RI Nomor 12. Tentang Jaminan Kesehatan.

Mitsui, T. 1997. New Cosmetic Science. Edisi Kesatu. Amsterdam: Elsevier Science B.V.

Mohammad, A., Mruthunjaya, K., Santhepete, N \& Manjula. 2016. Health Benefits of Morinda citrifolia L (Noni): A Review. Pharmacognosy Journal. Vol 8, Issue 4.
Z. Mohd Zin, A. Abdul Hamid, A. Osman, N. Saari \& A. Misran. 2007. Isolation and Identification of Antioxidative Compound from Fruit of Mengkudu (Morinda citrifolia L.). International Journal of Food Properties. 10:2, 363-373,

Monaj, A., Suva, Ankita, M., Patel, Neeraj, Sharma, C.B \& Ravi, K.M. 2014. Aksharpreet Institute of Pharmacy, Lakhabaval Road, Jamnagar, Gujarat, India.

Olivia, C. Simatupang, Jemmy Abidjulu, \& Krista V. Siagian. 2017. Uji daya hambat ekstrak daun mengkudu (Morinda citrifolia L.) terhadap pertumbuhan Candida albicans secara in vitro. Jurnal eGiGi (eG). 5(1):1-6

Pelczar, Michael J. \& Chan E.C.S. 2008. Dasar Dasar Mikrobiologi Jilid I. Jakarta: UI Press.

Sridevi, N., Changam, S \& Kotturathu M. 2013. Morinda Citrifolia- A Detailed Review. Departement Of Cellular \& Molecular Biochemistry, Heart Foundation, Mogappair, Chennai-600 101

Voight, R. 1994. Buku Pelajaran Teknologi Farmasi. Terjemahan : S. Noerono. Gadjah Mada University Press. Indonesia. 